\title{
AN ANALYSIS OF EFL LEARNERS' VOCABULARY AND LEXICAL COLLOCATIONAL KNOWLEDGE
}

\author{
Ardi Nugroho* \\ English Language and Culture Department, Bunda Mulia University
}

Received on 2 August 2017 / Approved on 25 September 2017

\begin{abstract}
One of the problems that EFL learners, more specifically Indonesian learners of English, often face deals with collocation. A possible reason for why learners often make inaccurate collocations is the influence of the learners' L1 or mother tongue. Another likely reason for the learners' inability to produce native-like collocations is their lack of vocabulary knowledge. So how exactly does one measure learners' vocabulary knowledge? One way of doing it is by looking at their vocabulary size and depth as well as their receptive and productive vocabulary. From this, the writer has become interested in exploring the relationship between learners' vocabulary and collocational knowledge, as well as the learners' L1 influence on their collocation recognition and production. The source of data for the current research is students from the second and fourth semesters of the English Language and Culture department at Bunda Mulia University. In order to measure these variables, the following tools are used: the Vocabulary Size Test (Nation and Beglar, 2007), the Words Associate Test (Read, 1998) and an adapted version of Gyllstad's (2007) receptive and Nikonzika's (2012) productive collocation tests. Each of the variables is analyzed using the Pearson product-moment correlation. The findings show that there is a significant positive correlation between the students' vocabulary knowledge and English lexical collocational knowledge. It is also found that the students' L1 directly influences their recognition and production of English lexical collocations.
\end{abstract}

Keywords: vocabulary size and depth, receptive and productive collocation

\section{ABSTRAK}

Salah satu masalah yang sering dihadapi pelajar Bahasa Inggris sebagai bahasa asing, khususnya pelajar Indonesia, berhubungan dengan kolokasi. Alasan kenapa peserta didik sering membuat kolokasi yang tidak akurat adalah kemungkinan adanya pengaruh L1 atau bahasa ibu pelajar. Kemungkinan alasan lain untuk ketidakmampuan pelajar untuk menghasilkan kolokasi seperti penutur asli Bahasa Inggris adalah kurangnya pengetahuan mereka mengenai kosa kata. Jadi, bagaimana tepatnya mengukur pengetahuan kosakata pelajar Bahasa Inggris? Salah satu cara untuk melakukannya adalah dengan melihat ukuran kosa kata mereka dan kedalaman serta kosakata reseptif dan produktif mereka. Dari hal ini, penulis menjadi tertarik untuk menjelajahi hubungan antara kosakata dan pengetahuan kolokasi, serta pengaruh bahasa ibu pada kemampuan kolokasi mereka. Sumber data untuk penelitian ini adalah mahasiswa dari semester dua dan empat dari jurusan Bahasa dan Budaya Inggris di Universitas Bunda Mulia. Untuk mengukur variabel-variabel ini, alat-alat berikut digunakan: Vocabulary Size Test (Nation dan Beglar, 2007), Word Association Test (Read, 1998) dan versi yang disesuaikan dari Receptive Collocation Test milik Gyllstad (2007) dan Productive Collocation Test milik Nikonzika (2012). Masing-masing variabel dianalisis menggunakan Korelasi Pearson. Temuan menunjukkan bahwa ada korelasi positif yang signifikan antara pengetahuan kosakata mahasiswa dan pengetahuan kolokasi leksikal Inggris mereka. Juga ditemukan bahwa bahasa Ibu mahasiswa secara langsung mempengaruhi pengenalan dan produksi kolokasi leksikal bahasa Inggris mereka.

Kata Kunci: ukuran dan kedalaman kosakata, kolokasi reseptif dan produktif

\footnotetext{
*Author(s) Correspondence:

E-mail: anugroho@bundamulia.ac.id
} 


\section{INTRODUCTION}

\section{Background of Study}

One of the problems that EFL learners, more specifically Indonesian learners of English, often face deals with collocation, or the combination of words which typically co-occur with one another. This is evident from their speech and writing, where they would often produce collocations that may seem awkward because it is not the common way of combining the words. Even learners who are fluent in speaking or good in writing may not always be able to come up with accurate collocations. In other words, their sentences may be grammatically correct, but they may not always sound natural in terms of word combination choices.

A possible reason for why learners often make inaccurate collocations is the influence of the learners' L1 or mother tongue. The learners would usually string words together in English in the same manner that they would in Indonesian. For example, they would come up with word combinations such as 'pull a conclusion' or 'set the bed' since in Indonesian, the common way of saying these are menarik kesimpulan and menata tempat tidur. These kinds of collocations basically show that they still think of what to say in Indonesian first and then translate it into English in a more or less literal way. Nonetheless, as can be seen from the two examples above, when the learners do this, they would end up producing uncommon word combinations.

Another likely reason for the learners' inability to produce native-like collocations is their lack of vocabulary knowledge. To put it simply, the learners do not know what words to use or combine with other words to produce appropriate collocations. For instance, they may come up with a collocation like 'do suicide' since they do not know the word 'commit,' which is the common word that goes with 'suicide.' The less vocabulary that they know, the more likely the learners would make errors in their collocations as they would only use the limited lexical items at their disposal to string words together. So how exactly does one measure learners' vocabulary knowledge? One way of doing it is by looking at their vocabulary size and depth. Besides size and depth, vocabulary can also be differentiated into receptive and productive vocabulary knowledge.

It has been found that vocabulary size plays an important role in determining learners' ability to perform on various reading comprehension questions (Alavi and Akbarian, 2012) and their ability to produce writings with high lexical richness (Azodi, et al., 2014). These previous studies have revealed a strong positive correlation, which means that a learner with high vocabulary size will most likely be able to answer reading comprehension questions well and create writings which are lexically rich. Another study by Mutlu and Kaşlioğlu (2016) also investigated the relation between vocabulary size and collocational knowledge. The result of this research shows that a learner's vocabulary size will also reflect their collocational knowledge, in the sense that a learner with a big vocabulary size will most likely have good collocational knowledge.

\section{Statement of Problem and Research Questions}

The production of collocation by EFL learners has become a widely discussed issue as of late. When people communicate, be it spoken or written, they will of course string many words together to form meaningful utterances and sentences. When doing so, it is important that they make proper collocations and combine words in a commonly accepted way. However, for many EFL learners, especially in Indonesia, this is still a serious problem. They often fail to make appropriate combination of words and end up producing collocations which are 'unnatural' from the perspective of a native speaker of English. These uncommon collocations may lead to misunderstanding, or at the very least, make it difficult for people to fully comprehend what the speaker is saying.

\footnotetext{
*Author(s) Correspondence:

E-mail: anugroho@bundamulia.ac.id
} 
One possible cause for the students' difficulty in producing accurate collocations is the influence of their L1, in this case the Indonesian language. They would often make word combinations in English based on how they would normally make it in Indonesian, e.g. 'do an attempt' because it is common to say melakukan usaha in Indonesian. Thus, it can be said that the students' L1 still plays a significant role in determining how they would produce English lexical collocations. Another probable reason for this may be due to the students' lack of vocabulary knowledge. Indonesian students often have trouble expressing their thoughts and ideas accurately because they do not know what exact words to use. In other words, it can be said that they have a low vocabulary size, or they do not have enough English lexical items at their disposal. If they do not even know what to say, how are they supposed to be able to string words together to produce proper English lexical collocations? Furthermore, does that mean that a person with a high vocabulary size will necessarily come up with accurate and proper collocations?

Based on the description above, the writer has become interested in exploring the relationship between learners' vocabulary size and their collocational knowledge. The writer would like to see whether the number of words the students know influences the students' ability to recognize and produce accurate English lexical collocations. Besides this, the writer would also like to investigate the relation between vocabulary depth and receptive and productive collocation, to examine whether the students' knowledge of words would affect their ability to identify and make proper collocations. Moreover, it would also be interesting to observe how the students' L1 or Indonesian language affects their recognition and production of English collocations. Lastly, this study is an attempt to see whether there is a difference between the result from the second semester students and the fourth semester students. From these, the following research questions are formulated:
1) How do the students' vocabulary size and depth relate with their receptive and productive collocation knowledge?

2) How do the students' L1 influence their recognition and production of English lexical collocations?

3) What are the differences between the results of the second and fourth semester students?

\section{Research Objectives}

Seeing as EFL learners, in this case Indonesian learners of English, often have difficulty producing proper English lexical collocations, the current study would like to examine more closely whether there is a correlation between vocabulary knowledge, more specifically size and depth, and collocational knowledge, both receptive and productive. To put it simply, the purpose of this research is to find out whether the learners' vocabulary knowledge would affect the way they recognize and produce proper English lexical collocations. Moreover, this research also aims to see how the students' L1 or Indonesian language influences their receptive and productive collocational knowledge. Lastly, the research is aimed at exploring the difference in result between the students from the second and the fourth semesters. It is expected that there should be a difference since the students from the fourth semester have learned English in the university longer and should have better vocabulary and lexical collocational knowledge in general.

\section{Research Significance}

The significance of the present study lies in the information regarding the relationship between vocabulary knowledge and collocational knowledge. More specifically, it is important to find out to what extent size and depth play a role in determining the success of recognizing and producing proper and accurate English lexical collocations. It is also imperative that the influence of the learners' L1 on collocational knowledge is explored. It is hoped that the findings would shed some light into these matters and could become a sort of basis for

\footnotetext{
*Author(s) Correspondence:

E-mail: anugroho@bundamulia.ac.id
} 
future teaching practices, especially the teaching of vocabulary and English lexical collocation. Lastly, it is also hoped that from the result of the study, the difference between the students from the two different semesters is made clear, so that it would give some insights into what should be done to improve vocabulary and collocation teaching and learning in general.

\section{THEORETICAL FRAMEWORK}

\section{Previous Studies}

The topic of vocabulary size has been getting a lot of attention lately, which can be seen from the growing number of studies that explore this topic. One such study is the one conducted by Mutlu and Kaşlioğlu (2016), who investigated the relation between Turkish EFL learners' vocabulary size and collocational knowledge. The collocation analyzed in this research is limited to verbnoun collocations. Based on the results of their research, they found that there is a strong positive correlation between the students' vocabulary size and their performance on the receptive and productive collocation test. Moreover, it was also found that the students had better receptive than productive collocational knowledge.

Another previous study related to vocabulary size and depth was done by Sen and Kuleli (2015). They explored the relation between EFL learners' vocabulary size and depth and reading performance. To measure the students' vocabulary size, the Vocabulary Size Test by Nation and Beglar (2007) was employed. Additionally, the Words Associate Test by Read (1998, as cited in Sen and Kuleli, 2015) was used to analyze their vocabulary depth. The findings show that both size and depth correlate significantly with the students' reading performance. However, the result revealed that between vocabulary size and depth, depth was the one that predicted reading performance better.

Referring to the two studies described above, the current study share some similarities. The most important similarity is the analysis of the learner's vocabulary size.
To measure this, all three researches employ the Vocabulary Size Test by Nation and Beglar (2007). Other than this, there are some slight differences between the three studies. For the first study, the difference with the current one lies in the inclusion of vocabulary depth. More specifically, the study by Mutlu and Kaşlioğlu (2016) only analyzes the relation between size and collocational knowledge without including vocabulary depth. As for the difference with the research from Sen and Kuleli (2015), theirs analyzes the relation between size and depth with reading performance and not collocational knowledge. So although both vocabulary size and depth are analyzed, the students' recognition and production of English lexical collocations are not the main focus of their research.

\section{Vocabulary Knowledge}

According to Schmitt (2014), vocabulary size deals with the total number of words that a person knows. In other words, all of the words that a person recognizes and understands make up the person's overall vocabulary size. On the other hand, vocabulary depth involves the knowledge of how well a person knows a particular word. So in here, it is not just about recognizing and understanding a word, but also the relationship between that word and other words, e.g. the synonyms, antonyms, etc.

Additionally, Laufer and Goldstein (2004 as cited in Pignot-Shahov, 2012) classify vocabulary knowledge into receptive and productive. Receptive vocabulary is related to passive skills like reading and listening, whereas productive vocabulary is concerned with more active skills such as speaking and writing. To be more specific, receptive knowledge encompasses a learner's ability to recognize and understand words when he or she reads or hears them. For instance, when a learner reads or hears the word 'obtain' and understands the meaning and how to use the word, it shows that the learner has receptive knowledge of that word. In contrast, a learner's productive knowledge is reflected through their ability to use the

\footnotetext{
*Author(s) Correspondence:

E-mail: anugroho@bundamulia.ac.id
} 
vocabulary repertoire available to them in active speech and writing. For example, if a learner knows the word 'acquire' and is able to use this word in his or her writing or speech, it means that he or she has productive knowledge of that word. To sum up, although both receptive and productive vocabulary knowledge are basically related to the lexical items in a learner's repertoire, it should be noted that these two are often clearly differentiated. More specifically, just because a learner knows a particular word (receptive) does not necessarily mean that he or she would be able to produce that word actively when he or she writes or speaks. In fact, it has been found that EFL learners usually understand what a particular word means, but fail to use the word in his or her writing and speech. This is especially true for low frequency and academic words.

\section{Collocational Knowledge}

Collocation is defined by Conzett (2001) as "Two or more words that tend to occur together (collocate)." Furthermore, McEnery et al. (2006) state that collocation is "the characteristic co-occurrence patterns of words, i.e., which words typically co-occur in corpus data." From these two definitions, it could be said that collocation is the combination of two or more words that commonly appear together and can be found in corpus data. For example, words like 'conduct' and 'do' typically occur together with 'research', but does not with the word 'make.' It should be highlighted that the 'typical' here is based on the perspective of native speakers of English. In other words, it is how native speakers normally combine the words. So if non-native speakers of English make collocations which are not common from the point of view of natives, it could be considered as an inaccurate collocation.

Furthermore, Benson et al. (1997) classify collocations into grammatical and lexical collocation. The first is defined as "a phrase consisting of a dominant word (noun, adjective, verb) and a preposition or grammatical structure such as an infinitive or clause." An example of this would be 'interested in,' where the adjective 'interested' is commonly combined with the preposition 'in.' This is considered to be a fixed grammatical collocation since the preposition 'in' cannot really be replaced by other prepositions like 'at' or 'on.' While lexical collocation is the combination of words which "...normally do not contain prepositions, infinitives, or clauses. Typical lexical collocations consist of nouns, adjectives, verbs, and adverbs." Hence, different with grammatical collocation which usually includes some grammatical elements, lexical collocation combines only dominant words. Some example combinations are verb + noun, adjective + noun, and verb + adverb. So 'serious problem' is an example of lexical collocation because it combines two dominant words, the adjective 'serious' and the noun 'problem.' It is also fixed because it cannot be substituted with a similar adjective like 'severe.' In other words, it is common to say 'serious problem' but not 'severe problem' even though the two adjectives are to some extent synonymous in meaning.

\section{RESEARCH METHOD}

\section{Source of Data}

The source of data for the current research is students from the second and fourth semesters of the English Language and Culture department at Bunda Mulia University. To be precise, the data that are analyzed are their vocabulary size and depth, as well as their receptive and productive collocational knowledge. The reason for selecting the second and fourth semester students as the respondents is that the writer would like to see how big of a vocabulary size and depth that students, who have studied less than two years in the English department, possess. It is expected that they may not have a wide array of lexical items at their disposal, nor that they have extensive collocational knowledge since they have only begun to study English formally at the university level. There is a total of nineteen (19) students from the second semester and twenty-seven (27) students from

\footnotetext{
*Author(s) Correspondence:

E-mail: anugroho@bundamulia.ac.id
} 
the fourth semester who are used as the respondents for the current study.

\section{Research Instrument}

There are several instruments that are used in this research. First, in order to measure the students' vocabulary size, the Vocabulary Size Test by Nation and Beglar (2007) is utilized. Second, the Words Associate Test by Read (1998, as cited in Sen and Kuleli, 2015) is used to analyze the students' vocabulary depth. Lastly, an adapted version of Gyllstad's (2007) receptive and Nikonzika's (2012) productive collocation tests are employed for examining the students' collocational knowledge.

\section{Data Collection Procedures}

The data collection procedure basically involves distributing the four tests described above to the students from the second and fourth semesters. Seeing as there are quite a lot of tests to be done, the tests are distributed in two separate sessions. The first session is for the vocabulary tests and the second session is for the colocation tests. The students are given around 30 minutes to 1 hour to finish the tests in each session.

\section{Data Analysis Procedures}

After administering the tests to the students, the first step is to analyze the correlation between their vocabulary size and depth and their receptive and productive collocational knowledge. Each of the variables is analyzed using the Pearson product-moment correlation. The result of the calculation provides answers to the first research question, i.e. to see whether their vocabulary knowledge affects the students' ability to recognize and produce accurate English lexical collocations. All of the correlation calculations are done using the SPSS 23 software. Furthermore, once the analysis on the relation between the variables previously described is already complete, the next step of the data analysis procedure involves investigating the influence of the students' L1 or Indonesian language towards their recognition and production of collocations. More specifically, the students' errors in identifying and making collocations are examined to see whether they are affected by their mother tongue. Finally, the result between the second and fourth semester students are compared to examine the difference between the two semesters. The comparison is done qualitatively by comparing the highest and lowest scores as well as the average from both semesters.

\section{RESULTS AND DISCUSSION}

\section{Correlation of Students' Vocabulary and Lexical Collocational Knowledge}

The first research question deals with the correlation between the students' vocabulary knowledge and their lexical collocational knowledge. The students' vocabulary knowledge is divided into vocabulary size and depth, while their lexical collocational knowledge divided into receptive and productive collocation. The relation between these four variables is analyzed quantitatively using the Pearson productmoment correlation. The hypothesis for the correlation is as follows:

- Ho: There is no significant correlation between students' vocabulary knowledge and lexical collocational knowledge.

- Ha: There is a significant correlation between students' vocabulary knowledge and lexical collocational knowledge.

The analysis is also separated between the students from the second semester and the fourth semester students.

The correlations for the second semester students can be seen below:

\footnotetext{
*Author(s) Correspondence:

E-mail: anugroho@bundamulia.ac.id
} 
Table 5.1 Correlations of Second Semester Students

\begin{tabular}{|c|c|c|c|c|c|}
\hline & & Vocab_Size & Vocab_Depth & $\begin{array}{l}\text { Receptive } \\
\text { Collocation }\end{array}$ & $\begin{array}{l}\text { Productive } \\
\text { Collocation }\end{array}$ \\
\hline \multirow[t]{3}{*}{$\overline{\text { Vocab_Size }}$} & Pearson Correlation & 1 & $.765^{* *}$ & $.882^{* *}$ & $.795^{* *}$ \\
\hline & Sig. (2-tailed) & & .000 & .000 & .000 \\
\hline & $\mathrm{N}$ & 19 & 19 & 19 & 19 \\
\hline \multirow[t]{3}{*}{ Vocab_Depth } & Pearson Correlation & $.765^{* * *}$ & 1 & $.641^{* * *}$ & $.669^{* *}$ \\
\hline & Sig. (2-tailed) & .000 & & .003 & .002 \\
\hline & $\mathrm{N}$ & 19 & 19 & 19 & 19 \\
\hline \multirow[t]{3}{*}{ Receptive_Collocation } & Pearson Correlation & $.882^{* * *}$ & $.641^{* * *}$ & 1 & $.873^{* *}$ \\
\hline & Sig. (2-tailed) & .000 & .003 & & .000 \\
\hline & $\mathrm{N}$ & 19 & 19 & 19 & 19 \\
\hline \multirow[t]{3}{*}{ Productive_Collocation } & Pearson Correlation & $.795^{* *}$ & $.669^{* * *}$ & $.873^{* *}$ & 1 \\
\hline & Sig. (2-tailed) & .000 & .002 & .000 & \\
\hline & $\mathrm{N}$ & 19 & 19 & 19 & 19 \\
\hline
\end{tabular}

**. Correlation is significant at the 0.01 level (2-tailed).

The table above summarizes the relation between the second semester students' vocabulary and lexical collocational knowledge. First of all, the relation between the students' vocabulary size and receptive and productive collocational knowledge are 0.882 and 0.795 respectively. These results are higher than their critical value at both $5 \%$ and $1 \%$, which are 0.456 and 0.575 . Moreover, the Sig. (2-tailed) value for both receptive and productive lexical collocations are 0.000, which is lower than 0.05 . These show that the null hypothesis has been rejected and the alternate hypothesis has been accepted. In other words, there is a positive significant correlation between the students' vocabulary size and their receptive and productive collocation.

Besides the students' vocabulary size, their vocabulary depth also correlates strongly with their lexical collocational knowledge. It is apparent from the Pearson product-moment correlation result of 0.641 and 0.669 for receptive and productive collocation respectively. These results are again higher than the critical value at both $5 \%(0.456)$ and $1 \%(0.575)$, and the Sig. (2-tailed) results of 0.003 and 0.002 are lower than 0.05 . Hence, the alternate hypothesis is accepted. It should be noted however, that even though both vocabulary size and depth correlate positively with the students' collocational knowledge, size still has a higher result. In other words, the correlation is stronger compared to vocabulary depth.

Meanwhile, the relation of the fourth semester students' vocabulary and lexical collocational knowledge is presented in the following table:

Table 2. Correlations of Fourth Semester Students

\begin{tabular}{|c|c|c|c|c|c|}
\hline & & Vocab_Size & Vocab_Depth & $\begin{array}{l}\text { Receptive } \\
\text { Collocation }\end{array}$ & $\begin{array}{l}\text { Productive } \\
\text { Collocation }\end{array}$ \\
\hline \multirow[t]{3}{*}{ Vocab_Size } & Pearson Correlation & 1 & $.742^{* * *}$ & $.702^{* *}$ & $.515^{* *}$ \\
\hline & Sig. (2-tailed) & & .000 & .000 & .006 \\
\hline & $\mathrm{N}$ & 27 & 27 & 27 & 27 \\
\hline \multirow[t]{3}{*}{ Vocab_Depth } & Pearson Correlation & $.742^{* *}$ & 1 & $.537^{* *}$ & $.590^{* *}$ \\
\hline & Sig. (2-tailed) & .000 & & .004 & .001 \\
\hline & $\mathrm{N}$ & 27 & 27 & 27 & 27 \\
\hline
\end{tabular}

*Author(s) Correspondence:

E-mail: anugroho@bundamulia.ac.id 


\begin{tabular}{|c|c|c|c|c|c|}
\hline Receptive_Collocation & $\begin{array}{l}\text { Pearson Correlation } \\
\text { Sig. (2-tailed) } \\
\mathrm{N}\end{array}$ & $\begin{array}{r}.702^{* *} \\
.000 \\
27 \\
\end{array}$ & $\begin{array}{r}.537^{* *} \\
.004 \\
27 \\
\end{array}$ & $\begin{array}{r}1 \\
27 \\
\end{array}$ & $\begin{array}{r}.533^{* *} \\
.004 \\
27 \\
\end{array}$ \\
\hline Productive_Collocation & $\begin{array}{l}\text { Pearson Correlation } \\
\text { Sig. (2-tailed) } \\
\mathrm{N}\end{array}$ & $\begin{array}{r}.515^{* *} \\
.006 \\
27\end{array}$ & $\begin{array}{r}.590^{* *} \\
.001 \\
27\end{array}$ & $\begin{array}{r}.533^{* *} \\
.004 \\
27\end{array}$ & 27 \\
\hline
\end{tabular}

**. Correlation is significant at the 0.01 level (2-tailed).

From the table above, it can be seen that there is indeed a significant positive correlation between the students' vocabulary knowledge and English lexical collocational knowledge. In terms of vocabulary size, it correlates with the students' receptive collocations as much as 0.702 , whereas the correlation between vocabulary size and productive collocation is 0.515 . The correlation is significant at both $5 \%$ and $1 \%$ level, where the critical values of 0.381 and 0.487 are lower than the current result. The Sig. (2-tailed) score are 0 for the receptive collocation and 0.006 for the productive collocation, which also supports the rejection of the null hypothesis that there is no significant correlation between the three variables since they are lower than 0.05 .

Additionally, the result of the Pearson product-moment correlation reveals that it is not only size that correlates with the students' collocational knowledge, but vocabulary depth as well. This is shown from the table above where the score for the receptive collocation is 0.537 and 0.590 for the productive one, while the Sig. (2-tailed) is 0.004 and 0.001 for each. These results show that although vocabulary depth does not correlate as strongly as vocabulary size with receptive and productive collocations, there is still a significant relation between these variables.

Influence of $\mathrm{L} 1$ towards Recognition and Production of Lexical Collocations

To answer the second research questions, the influence of the students' L1 or Indonesian language towards their recognition and production of English lexical collocations is explored. As has been mentioned in the background, students often produce inaccurate collocations because they often make them based on how they would normally do it in their mother tongue. This is quite evident from the result of the collocation tests; for example, the combination of the verb 'set' and the noun 'bed.' A lot of the students identified this as the appropriate collocation as opposed to 'make + bed.' Actually, the more appropriate one is the latter, and the word combination of 'set + bed' is not the common one. However, most students chose the uncommon one since in Indonesian it is common to say menata tempat tidur. Thus, the students were influenced to select 'set + bed' over 'make + bed' because of the influence of their L1. Other examples include:

$$
\begin{aligned}
& >\text { pull }+ \text { conclusion (menarik kesimpulan) } \\
& ><\text { draw }+ \text { conclusion } \\
& >\text { do }+ \text { sacrifices }(\text { melakukan pengorbanan) } \\
& ><\text { make }+ \text { sacrifices } \\
& >\quad \text { do }+ \text { attempt }(\text { melakukan usaha })><\text { make } \\
& + \text { attempt }
\end{aligned}
$$

The examples above reveal that the students often fail at recognizing the accurate collocations for they choose the ones that are common to them in their mother tongue or Indonesian language. The combinations on the left are the inaccurate ones selected by the students, whereas the ones on the right are actually the appropriate ones.

Furthermore, in terms of productive collocations, the students also came up with some uncommon word combinations due to the influence of their Indonesian language. One such example is the combination of the verb 'find' and the noun 'gap.' It is common in Indonesian to say menemukan celah; therefore, some of the students produced the collocation 'find + gap' in English. In fact, the more common one would be the combination 'fill + gap.' However, since it may not be very common to say mengisi celah in Indonesian, many students produced the other inaccurate

\footnotetext{
*Author(s) Correspondence:

E-mail: anugroho@bundamulia.ac.id
} 
collocation. Some other evidence of the influence of the students' L1 towards their production of English lexical collocation is as follows:

receive + rank (menerima posisi) $><$ reach + rank

$>$ prepare + accommodation (menyiapkan akomodasi $)><$ provide + accommodation

Based on the examples above, it is clear that the students often produce inaccurate collocations due to the influence of their L1 or Indonesian language. The moment they think it is common in Indonesian language they just directly translate it into English and consider it to be accurate and natural. Nevertheless, when they do so, they end up making uncommon word combinations. The more appropriate ones should have been the ones on the right side from the examples above.

\section{Comparison of the Result of the Second and Fourth Semester Students}

Finally, in order to answer the last research question, which involves the difference between the second and the fourth semester students, a comparison of the result from both semesters is made. The descriptive statistics are as follows:

Table 3. Descriptive Statistics of Second and Fourth Semester Students

\begin{tabular}{|l|c|c|c|c|c|c|c|c|}
\hline \multirow{2}{*}{} & \multicolumn{2}{|c|}{ Vocabulary Size } & \multicolumn{2}{c|}{ Vocabulary Depth } & \multicolumn{2}{c|}{ Receptive Collocation } & \multicolumn{2}{c|}{ Productive Collocation } \\
\cline { 2 - 9 } & Sem 2 & Sem 4 & Sem 2 & Sem 4 & Sem 2 & Sem 4 & Sem 2 & Sem 4 \\
\hline Mean & 7258 & 6470 & 62 & 69 & 78 & 66 & 82 & 82 \\
\hline Range & 7300 & 5600 & 45 & 54 & 50 & 60 & 40 & 30 \\
\hline Minimum & 3500 & 4200 & 45 & 31 & 50 & 35 & 60 & 65 \\
\hline Maximum & 10800 & 9800 & 90 & 85 & 100 & 95 & 100 & 95 \\
\hline
\end{tabular}

The table above shows there are some differences in terms of average, range, minimum, and maximum scores from the second and fourth semester students. Firstly, in terms of vocabulary size, the second semester students have a higher average compared to the fourth semester students, i.e. 7,258 > 6,470 . The second semester also has a higher maximum score of 10,800 as opposed to 9,800 for the fourth semester. Nonetheless, the second semester has a lower minimum score compared to the fourth semester, which is 3,500 and 4,200 respectively. Next, the fourth semester students have a slightly higher average for vocabulary depth, i.e. 69 compared to 62 for the second semester students. However, both the minimum and maximum scores are higher for the second semester, which are 45 and 90 . The fourth semester has lower scores, which are 31 and 85 . Additionally, in terms of receptive collocation, the second semester students scored higher in average, minimum and maximum scores, which are 78, 50 and 100 respectively. On the other hand, the fourth semester students scored and average of 66 , with the lowest score being 35 and the highest 95. Lastly, both semesters have the same average score of 82 . The lowest score is from the second semester which is 60 , while the minimum score for the fourth semester is slightly higher, i.e. 65 . Nevertheless, the highest score is still from the second semester, which is 100 . The maximum score from the fourth semester is 95 .

Moreover, in terms of the correlations between the four variables discussed in the previous section, the summary of the comparison is presented in the following table:

*Author(s) Correspondence:

E-mail: anugroho@bundamulia.ac.id 
Table 4. Correlations between Students' Vocabulary Knowledge and English Lexical Collocational Knowledge

\begin{tabular}{|l|c|c|c|c|}
\hline \multirow{2}{*}{} & \multicolumn{2}{|c|}{ Receptive Collocation } & \multicolumn{2}{c|}{ Productive Collocation } \\
\cline { 2 - 5 } & Sem 2 & Sem 4 & Sem 2 & Sem 4 \\
\hline Vocab Size & 0.882 & 0.702 & 0.795 & 0.515 \\
\hline Vocab Depth & 0.641 & 0.537 & 0.669 & 0.590 \\
\hline
\end{tabular}

Based on the result above, it can be seen that the students from the second semester have higher correlations compared to the fourth semester students. Although all of the results show a significant positive correlation between the students' vocabulary size and depth and their receptive and productive collocation, the scores for the second semester are all higher than the fourth semester. In terms of vocabulary depth, the difference is not that much, that is:

$$
\begin{array}{ll}
\checkmark & \text { receptive: } 0.641-0.537=0.104 \\
\checkmark & \text { productive: } 0.669-0.590=0.079
\end{array}
$$

On the other hand, the difference is slightly higher for the correlation between the students' vocabulary size and their receptive and productive collocation:

$\checkmark$ receptive: $0.882-0.702=0.180$

$\checkmark$ productive: $0.795-0.515=0.280$

Next, the research questions formulated in chapter 1 are discussed in more detail. First of all, for the first question regarding the relation between the students' vocabulary knowledge and English lexical collocational knowledge, it is found that there is a positive significant correlation between these variables. This means that both vocabulary size and depth directly influences the students' receptive and productive collocations. The higher the size and depth, the better they are at recognizing and producing accurate English lexical collocations. This is clearly shown from the summary of the Pearson product-moment correlations in table 5.4 above. Nonetheless, it should be noted that between size and depth, the latter has a lower correlation result. In other words, vocabulary size affects the students' ability to recognize and produce proper lexical collocations more strongly compared to vocabulary depth. So the students are able to string words more accurately when they know more words or have a higher vocabulary size. Whereas the students vocabulary depth does not influence their collocational knowledge as much, or it can be said that even when a student has a lot of knowledge about a particular word, it does not necessarily guarantee that he or she will be able to combine that word properly with another word. Hence, it could be concluded that the recognition and understanding of words (vocabulary size) is perhaps slightly more important than broad and deep knowledge of words (vocabulary depth) when it is related to recognition and production of accurate English lexical collocations.

Furthermore, concerning the second research question about the influence of the students' L1 or Indonesian language towards their recognition and production of English lexical collocations, the previous section has already described how the students were in some cases directly influenced by their L1. More specifically, the students recognized and produced English lexical collocations which were inaccurate because they referred to the common way of combining the words in Indonesian, e.g. 'pull + conclusion' because it is common to say menarik kesimpulan in Indonesian language. This shows that the students still 'think' in Indonesian and try to transfer their knowledge from their L1 into English. Of course, when they do that, they end up with collocations which are not really common from the perspective of native speakers of English.

\footnotetext{
*Author(s) Correspondence:

E-mail: anugroho@bundamulia.ac.id
} 
Nevertheless, it is important to highlight that not all of the students' inaccurate collocations are caused by the influence of their L1. Another possible reason as to why they recognized and produced improper collocations might be due to their lack of vocabulary knowledge in general. For example, a lot of students selected 'receive + cold' over 'catch + cold,' probably because they do not realize that the verb 'catch' can be combined with the noun 'cold.' This inaccuracy is not caused by the students' L1 because the common verb combination for this word is terkena + pilek which would most likely be translated to 'exposed' or 'get' + 'cold,' which none of these are available in the selections. Thus, the incorrect identification of the proper collocation is probably due to their confusion of which to choose between 'receive' and 'catch,' which is the result of their lack of knowledge. Additionally, the students produced combinations such as 'see' or 'send' + 'soul.' The expected answer is actually 'sell' + 'soul,' but the students came up with those answers perhaps because they are unaware that the verb 'sell' can be combined with the noun 'soul,' not because it is influenced by their L1 since it is also not common to say melihat jiwa or mengirim jiwa in Indonesian language.

Last but not least, the third research question is aimed at exploring the differences in the result of the students' vocabulary knowledge and English lexical collocational knowledge from the second and fourth semesters. The findings of the current study reveal that there are several differences between the two semesters such as the averages, the maximum and minimum scores, as well as the correlations. Referring to table 5.3 from the previous section, it can be seen that overall the second semester students are slightly better than the fourth semester students since they have more or less higher average results in vocabulary size $(7,258>$ $6470)$, receptive collocation $(78>66)$, and higher maximum scores for all four variables (size: 10,800 > 9,800, depth: $90>85$, receptive collocation: $100>95$, and productive collocation: $100>95$ ). It should be noted that both semesters have the same average for the productive collocation, i.e. 82 , and the fourth semester students have a higher average for vocabulary depth $(69>62)$. The minimum scores of the second semester are also all higher than the fourth semester save for one, which is the vocabulary size, where the second semester's minimum score is 3,500 and the fourth semester's is 4,200 . As for the correlations, table 5.4 above shows that the second semester students have higher Pearson product-moment correlation scores for all four variables. The differences may not be that much, but they are still higher nonetheless. A possible reason as to the higher overall performance from the second semester students is that the students are better overall. There are some students who have very good English skills and knowledge from the start. So even though they have only started learning English at the university level for more or less one year, since they already joined the English department with good basics, they performed better in general compared to the fourth semester students. Of course, it does not mean that all of the students from the second semester are all good. There are some very weak students who also did not have very good results. Some of the students in the fourth semester are also quite weak, but they have learned English in the university for a year longer, so they performed slightly better than the weak students from the second semester in the end.

Seeing as the second semester students have higher overall results, it can be concluded that their vocabulary and English lexical collocational knowledge are better than that of the fourth semester students. Even though the reason might be because they have better basics in general, it cannot be denied that the fourth semester students, who have learned English approximately one year longer than their juniors, have lower results. This shows that the duration of study in the English department at Bunda Mulia University does not guarantee that the students will perform better than students who have learned English for a shorter period of time.

\footnotetext{
*Author(s) Correspondence:

E-mail: anugroho@bundamulia.ac.id
} 
Finally, one last finding that may be worth noting deals with the result of the students' receptive and productive collocations. In general, the students from both semesters have better scores for their productive collocation compared to their receptive collocation. That is, the second and fourth semester scored an average of 82 for their productive collocation, as opposed to the average of 78 from the second semester and 66 from the fourth semester for the receptive collocation. This is quite surprising as production is normally more difficult compared to reception. In other words, producing accurate English lexical collocations is usually more challenging than just recognizing the proper collocations. Even the result of the study from Mutlu and Kaşlioğlu (2016) revealed that the Turkish EFL learners had better receptive than productive collocational knowledge. The reason for this is perhaps the nature of the collocation tests themselves. Although the students only had to identify the proper English lexical collocations in the receptive test, they had more difficulty doing this test probably because the combination of words are unfamiliar to them or their L1 or Indonesian language influenced them to choose the inaccurate selections. On the other hand, in the productive collocation test, the students were already given clues, i.e. two letters from the verb that is expected for them to produce. The original test from Nikonzika's (2012) was actually also like this, where two letters from the verbs are provided. The reasoning for this is to limit the possible answer of the respondents. By providing two letters, it is hoped that the answers do not vary too much since there are multiple possible collocations. Nevertheless, by doing this, it made it easier for the students to come up with the correct and accurate collocations. In retrospect, if the clues had not been provided in the test, perhaps the students would have had more difficulty doing the test which would have led to lower results in the productive test compared to the receptive collocation test since production is normally harder than recognition.

\section{CONCLUSION}

Based on the research questions of the study as well as the findings and discussion described in the previous chapter, there are several conclusions that can be drawn. First of all, from the data analysis, it is found that there is a significant positive correlation between the students' vocabulary knowledge and English lexical collocational knowledge. More specifically, both vocabulary size and depth play an important role in determining the students' receptive and productive collocations. In other words, the higher the size and depth, the higher the students will be able to recognize and produce accurate English lexical collocations. In contrast, if the students have low vocabulary size and depth, they would most likely have difficulty combining words properly.

Next, the data show that the students L1 or Indonesian language directly affected the way they recognized and produced accurate collocations. This is especially true for the receptive collocation results where a lot of the students' inaccurate selections are made based on how they would normally make them in Indonesian. In other words, just because they thought that it is correct in their mother tongue, they also thought that it is the correct way in English as well. Nevertheless, when they do so, they end up combining the words in an uncommon way according to native speakers of English.

Last but not least, after comparing the result of the second and fourth semester students, it is found that there are some differences. In general, the second semester students have higher results compared to the fourth semester students, be it in terms of average vocabulary size, receptive, and productive collocations, as well as Pearson product-moment correlation scores. This basically means that the longer duration of study of the fourth semester students does not necessarily ensure that they would perform better or have better vocabulary and collocational knowledge compared to the second semester students who have just

\footnotetext{
*Author(s) Correspondence:

E-mail: anugroho@bundamulia.ac.id
} 
learned at the university level for approximately only a year. However, it should also be noted that overall, the second semester students have better English skills and knowledge compared to the fourth semester students who from the beginning were quite weak. Thus, even though the second semester students have learned English at the university for a shorter period, they performed better overall because they already had very good basics.

Next, to sum up the research, some suggestions are presented. Firstly, seeing as the scope of the study is quite small, i.e. only focusing on four variables (vocabulary size, depth, receptive and productive collocations), further studies which incorporate more variables related to vocabulary and collocations may give more elaborate conclusions regarding the relation between vocabulary and English lexical collocational knowledge. Second, in terms of respondents, this study is only limited to the second and fourth semester students. Perhaps a larger number of respondents would have yielded different results and findings. Finally, the most important suggestion that can be made concerns the vocabulary and collocation teaching implications. The findings show that the second semester students have better overall results, which means that even after studying English for two years the fourth semester students have low English knowledge in terms of vocabulary and collocation. Therefore, it is suggested that the lecturers teach these two subjects more intensely and comprehensively even from the very beginning of their study in the university. Vocabulary and collocations should also be taught directly and explicitly so that the students are made aware of the accurate way of combining words together and so that their L1 or Indonesian language does not affect them too much. By doing this, it is hoped that the students will improve their English proficiency in general, and more specifically their vocabulary and lexical collocational knowledge.

\section{REFERENCES}

Alavi, S.M., \& Akbarian, I. (2012). The role of vocabulary size in predicting performance on TOEFL reading item types. System, 40, 376-385.

Azodi, N., Karimi, F., \& Vaezi, R. (2014). Measuring the lexical richness of productive vocabulary in Iranian EFL university students' writing performance. Theory and Practice in Language Studies, 4 (9), 1837-1849.

Benson, M., Benson, E., \& Ilson, R. (1997). The BBI Dictionary of English Word Combinations (Revised Edition). Amsterdam: John Benjamins Publishing Company.

Conzett, J. (2001). Integrating collocation into a reading and writing course. Michael Lewis (Ed.), Teaching Collocation Further Developments in the Lexical Approach, 70-87. Hove, England: Language Teaching Publications.

Gyllstad, H. (2007). Testing English collocations: Developing receptive tests for use with advanced Swedish learners. Published Doctoral Dissertation. Lund University, Stockholm, Switzerland.

McEnery, T., Xiao, R., \& Tono, Y. (2006). Corpus-based language studies: an advanced resource book. New York: Routledge.

Mutlu, G., \& Kaşlioğlu, Ö. (2016). Vocabulary size and collocational knowledge of Turkish EFL learners. Journal of Theory and Practice in Education, 12 (6), 12311252.

Nation, I.S.P., \& Beglar, D. (2007). A vocabulary size test. The Language Teacher, 31 (7), 9-13.

Nizonkiza, D. (2012). Quantifying controlled productive knowledge of collocations across proficiency and word frequency levels. Studies in Second Language Learning and Teaching, 2 (1), 67-92.

Nugroho, A. (2015). The correlation between students' vocabulary size and TOEFL reading comprehension. Unpublished Research. Jakarta: Bunda Mulia University.

\footnotetext{
*Author(s) Correspondence:

E-mail: anugroho@bundamulia.ac.id
} 
- (2016). An analysis of EFL learners' vocabulary size and lexical richness in writing. Unpublished Research. Jakarta: Bunda Mulia University.

Pignot-Shahov, V. (2012). Measuring L2 receptive and productive vocabulary knowledge. Language Studies Working Papers, 4, 37-45.
Schmitt, N. (2014). Size and depth of vocabulary knowledge: what the research shows. Language Learning, 64(4), 913-951.

Sen, Y., \& Kuleli, M. (2015). The effect of vocabulary size and vocabulary depth on reading in EFL context. Procedia Social and Behavioral Sciences, 199, $555-562$.

\section{Appendix 1: Adapted Word Associate Test (Read, 1998)}

\section{Word Associate Test}

\section{Instructions:}

This is a test of how well you know the meaning of adjectives that are commonly used in English.

Each item looks like this:

sudden

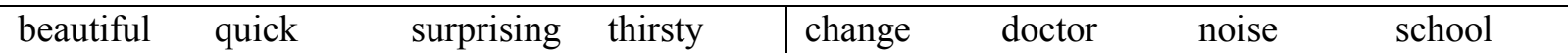

- The words on the left side may help to explain the meaning of "sudden".

- The words on the right side are nouns that may come after "sudden" in a phrase or a sentence.

- "Sudden" means "happening quickly and unexpectedly," so the correct answers on the left side are "quick" and "surprising".

- We do not normally say "a sudden doctor" or "a sudden school," but we often say "a sudden change" and "a sudden noise," so "change" and "noise" are the correct answers on this side.

* From the two boxes in each number below, circle four words that you think are relevant to the stimulus word according to the criteria mentioned above. Not all answers will be 2 on the left and 2 on the right. There may be some that are only 1 correct answer either on the left or on the right side.

1. beautiful

\begin{tabular}{|lll|lll}
\hline enjoyable expensive free & loud & education face & music & weather
\end{tabular}

2. bright

\begin{tabular}{|lll|llll|}
\hline clever famous & happy & shining & colour & hand & poem & taste \\
\hline
\end{tabular}

\section{3. calm}

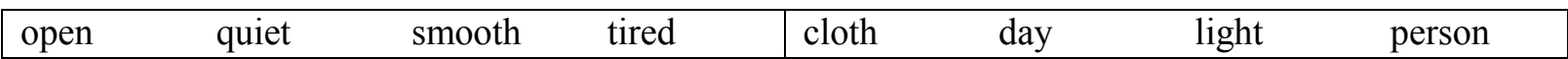

*Author(s) Correspondence:

E-mail: anugroho@bundamulia.ac.id 
4. natural

\begin{tabular}{lll|lll} 
expected helpful real short & foods neighbours parents songs
\end{tabular}

5. fresh

\begin{tabular}{|lll|lll|}
\hline another cool & easy & cotton & heat & language & water \\
\hline
\end{tabular}

6. general

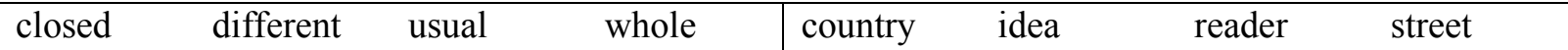

\section{7. bare}

\begin{tabular}{|lll|lll|}
\hline empty heavy & uncovered useful & cupboard feet & school tool \\
\hline
\end{tabular}

8. acute

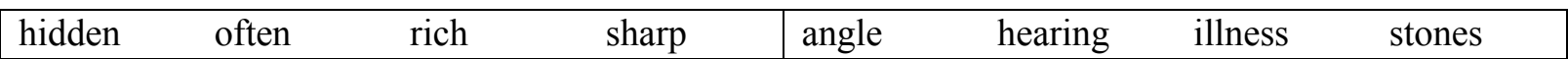

9. common

\begin{tabular}{|lll|llll|}
\hline complete light & ordinary & shared & boundary & circle & name & party
\end{tabular}

10. complex

\begin{tabular}{|c|c|c|c|c|c|c|c|}
\hline angry & difficult & necessary & sudden & argument & passengers & patterns & problem \\
\hline \multicolumn{8}{|c|}{ 11. broad } \\
\hline full & moving & quiet & wide & night & river & shoulder & smile \\
\hline
\end{tabular}

12. conscious

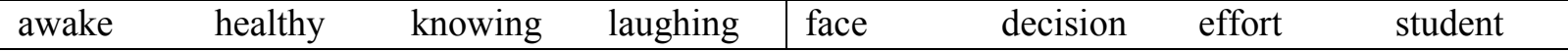

13. convenient

\begin{tabular}{|lll|lll|}
\hline easy & fresh & near & suitable & experience & sound \\
\hline
\end{tabular}

\section{4. dense}

\begin{tabular}{|lll|llll}
\hline crowded hot & noisy & thick & forest & handle smoke weather \\
\hline
\end{tabular}

15. curious

\begin{tabular}{|lll|llll|}
\hline helpful interested missing & strange & accident & child & computer & steel \\
\hline
\end{tabular}

16. distinct

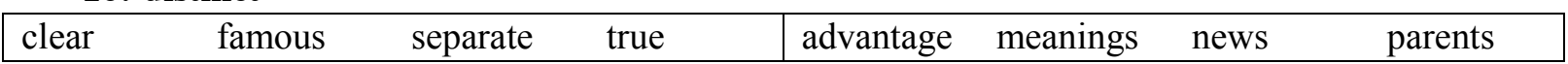

17. dull

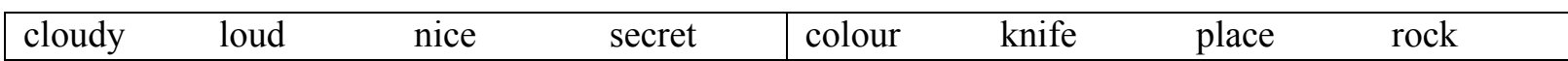

18. direct

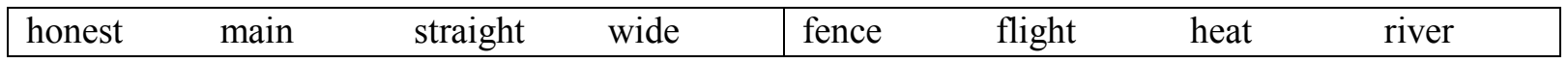

*Author(s) Correspondence:

E-mail: anugroho@bundamulia.ac.id 


\section{9. favorable}

\begin{tabular}{|lll|lll} 
helpful legal & possible positive & habit & response teacher
\end{tabular}

\section{0. secure}

\begin{tabular}{|lll|llll|}
\hline confident & enjoyable fixed & safe & game & job & meal & visitor \\
\hline
\end{tabular}

Appendix 2: Adapted Collocation Test (Gyllstad, 2007; Nikonzika, 2012)

\section{Collocation Test A}

\section{Instructions:}

Look at the following test items. Each test item contains two word combinations (A and B). One of the two combinations is a natural and frequent word combination that occurs in the English language. Choose which one is the most natural combination by circling either A or B for each test item.

Example: $\quad$ A) do a mistake B) make a mistake

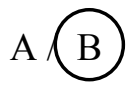

\begin{tabular}{|l|l|l|l|l|}
\hline No. & A & B & & \\
\hline 1. & do damage & make damage & A & B \\
\hline 2. & put out a fire & turn out a fire & A & B \\
\hline 3. & hold discussions & make discussions & A & B \\
\hline 4. & receive a cold & catch a cold & A & B \\
\hline 5. & pay a visit & do a visit & A & B \\
\hline 6. & fell tears & shed tears & A & B \\
\hline 7. & sweep the floor & brush the floor & A & B \\
\hline 8. & grab an opportunity & seize an opportunity & A & B \\
\hline 9. & set the bed & make the bed & A & B \\
\hline 10. & draw a conclusion & pull a conclusion & A & B \\
\hline 11. & perform suicide & commit suicide & A & B \\
\hline 12. & tell a prayer & say a prayer & A & B \\
\hline 13. & hold a speech & give a speech & A & B \\
\hline 14. & do sacrifices & make sacrifices & A & B \\
\hline 15. & fell bombs & drop bombs & A & B \\
\hline 16. & brush shoes & polish shoes & A & B \\
\hline 17. & make apologies & do apologies & A & B \\
\hline 18. & make an attempt & do an attempt & A & B \\
\hline 19. & hold one's breath & keep one's breath & A & B \\
\hline 20. & pursue a career & do a career & A & B \\
\hline
\end{tabular}

*Author(s) Correspondence:

E-mail: anugroho@bundamulia.ac.id 


\section{Collocation Test B}

\section{Instructions:}

Complete the underlined words in the sentences below with the best verb that collocates with the underlined noun. The first two letters of the word is already provided.

Example: $\quad$ She is conducting campaigns to at......... new clients.

She is conducting campaigns to attract new clients.

1. I ha no intention of changing jobs because I am happy where I am.

2. Better sa your energy not trying to persuade people who are not interested.

3. She asked him if he could ke a secret before telling him the horrible story.

4. She felt she would ma a terrible mess of her life if she were to throw everything overboard now.

5. Her appointment will fi the gap created when the marketing manager left.

6. It is common practice that when a song ends, the performer has to ta a bow.

7. Victory will br glory, fame, and riches to the football team.

8. In May and June, females leave the males to bu a nest and incubate their eggs.

9. She joined the navy where she expects to re the rank of captain before retiring.

10. He is a person who can se his soul to the devil provided he gets money.

11. When she got pregnant at the age of 16 , she decided to ha an abortion.

12. The estate expects to ho an auction to raise money.

13. She had a short time to dress and ap lipstick before rushing out to the party.

14. He vowed to ta revenge on the man who had killed his brother.

15. She was hoping she would not have to gi evidence in court.

16. I can't re any conclusions from their vague observations.

17. With the new computer, you can ha access to all the files.

18. The mechanic can ma the necessary adjustments to the broken engine.

19. We have to fo the safety guidelines laid down by the government.

20. It is the duty of the local community to pr accommodation for the homeless.

*Author(s) Correspondence:

E-mail: anugroho@bundamulia.ac.id 